\title{
Nanostructured Coatings Based on Amorphous Carbon and Gold Nanoparticles Obtained by the Pulsed Vacuum-arc Method
}

\author{
A.Ya. Kolpakov ${ }^{1}$, M.G. Kovaleva1,*, V.M. Beresnev², S.S. Manokhin ${ }^{1,3}$, A.I. Poplavsky ${ }^{1,4}$, A.N. Khmara ${ }^{1}$, \\ M.V. Mishunin ${ }^{1}$, M.E. Galkina ${ }^{1}$, J.V. Gerus ${ }^{1}$, M.N. Yapryntsev ${ }^{1}$, V.V. Sirota ${ }^{4}$, O.V. Glukhov ${ }^{5}$ \\ ${ }^{1}$ Belgorod National Research University, 85, Pobedy St., 308015 Belgorod, Russia \\ ${ }^{2}$ V.N. Karazin Kharkiv National University, 4, Svobody Sq., 61000 Kharkiv, Ukraine \\ ${ }^{3}$ Institute of Problems of Chemical Physics, Russian Academy of Sciences, 1, Akad. Semenov Prosp., \\ 142432 Chernogolovka, Moscow Region, Russia \\ ${ }^{4}$ Belgorod State Technological University named after V.G. Shoukhov, 46, Kostyukov St., 308012 Belgorod, Russia \\ ${ }^{5}$ National University of Radio Electronics, 14, Science Boulevard, 61166 Kharkiv, Ukraine
}

(Received 14 June 2019; revised manuscript received 05 August 2019; published online 22 August 2019)

\begin{abstract}
Nanostructured coatings based on diamond-like carbon and gold-doped carbon with a thickness of 100$300 \mathrm{~nm}$ were obtained by a pulsed vacuum-arc method on silicon substrates. The structure of the coatings was studied by high-resolution transmission electron microscopy, the elemental composition was studied by X-ray microanalysis. In addition, hardness, adhesive and tribological characteristics, the magnitude of internal stresses, as well as electrical conductivity and optical characteristics were also investigated. It was found that gold nanoparticles in the carbon matrix have a crystal structure and their size is about $5 \mathrm{~nm}$. A change in the gold content from 1 to $25 \%$ leads to a deterioration in the tribological properties of the coating, while the resistivity decreases from 920 to $0.06 \mathrm{~m} \Omega \cdot \mathrm{m}$. The technique proposed in this study for the doping of a diamond-like carbon coating with gold allows varying the resistivity and transmittance over a wide range while maintaining high wear resistance and low friction coefficient.
\end{abstract}

Keywords: Amorphous carbon, Gold nanoparticles, Pulsed vacuum-arc method, Microstructure, Electrical conductivity, Optical properties.

DOI: 10.21272/jnep.11(4).04019

PACS numbers: 68.55.aj, 68.37.Ps

\section{INTRODUCTION}

In recent years, plasmonics has become an independent scientific area with numerous applications, including nanosensors [1,2]. Gold and silver nanoparticles are considered as promising materials for use in plasmonics [3]. The promise of DLC coatings for the protection of nanostructures was shown [4]. In addition, there are promising areas of application for thin coatings that require high tribological characteristics, as well as electrical conductivity and certain optical characteristics. Aerospace industry is one of those areas where gold and silver based coatings are used [5]. This direction was developed using diamond-like carbon and gold layers [6]. To develop durable conductive lubricating films, tribology of nanocomposite coatings consisting of carbon and silver or gold was studied [7]. Nanocomposite films with 50 and 30 at. \% gold content were deposited on silicon (100) substrates by radio frequency sputtering of carbon targets, as well as semicircular and sector gold or silver targets. The content of silver or gold in the coating was dependent on the type of target. To increase the electrical conductivity, a layer of $\mathrm{Ag}$ or $\mathrm{Au}$ was deposited first, and then a layer of carbon was deposited. By repeating these deposition stages, nanostructured multilayer films of four types were prepared, as well as single-layer $\mathrm{Au}, \mathrm{Ag}$ and $\mathrm{C}$ coatings. Coatings were obtained by magnetron sputtering of graphite, gold, silver targets, as well as combined targets consisting of these materials. It has been shown that composite coatings surpass coatings based on a single material in a number of properties.

We have previously shown the possibility of using the pulsed vacuum-arc method to obtain nanostructured coatings based on carbon and silver [8]. In particular, the influence of the substrate on the size and distribution density of silver nanoclusters in the a-C:Ag coating was established. It was shown that the formation rate of amorphous carbon based coating doped with silver affects the number and size of silver nanoclusters.

The properties of diamond-like carbon and gold based coatings obtained by a pulsed vacuum-arc method combining high tribological characteristics and electrical conductivity are of particular interest for the study, given that the physical and mechanical properties of the coatings obtained by the magnetron method are significantly inferior to the properties of the coatings obtained by vacuum arc spraying methods [9].

\section{EXPERIMENTAL PROCEDURE}

Coatings based on carbon and gold-doped carbon were obtained on an experimental setup equipped with an oilfree vacuum pumping system using a pulsed vacuum-arc plasma source of the original design shown in Fig. 1a. A cathode made of MPG-6 graphite with a diameter of $30 \mathrm{~mm}$ (1) contained inserts made of $99.9 \%$ pure gold (2) with a diameter of $2 \mathrm{~mm}$. Increasing the number of inserts allowed to increase the gold content in the coating.

Fig. $1 \mathrm{~b}$ shows the cathode assembly of a pulsed vacuum-arc plasma source with four gold inserts and traces of erosion. In addition, a pulsed vacuum-arc plasma source with a graphite cathode without inserts was used. The control algorithm for the operation of these two sources made it possible to obtain coatings with different gold contents (from 0 to $25 \%$ ). A capacitive storage (3) with a total capacity of $2000 \mu \mathrm{F}$ was used, charging up to $300 \mathrm{~V}$

*Kovaleva@bsu.edu.ru 
from a constant current source (not shown in the figure). The discharge was initiated using an additional ignition pulse applied to the ignition electrode (4), separated from the cathode by a dielectric ring (5). The pulse repetition rate of the ignition was $1-5 \mathrm{~Hz}$. The discharge pulse duration was set using a pulse shaper (6) within 0.8-1.0 ms. Performance of this source was $0.6-0.7 \mathrm{~nm} /$ pulse at a distance of $100 \mathrm{~mm}$ from the cathode.

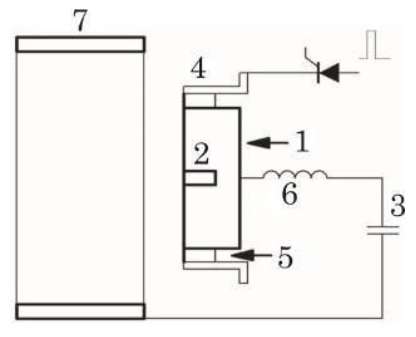

a

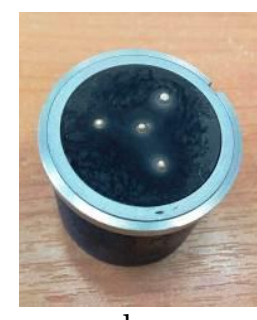

$\mathrm{b}$
Fig. 1 - (a) Pulsed vacuum-arc plasma source: 1-graphite cathode; 2 -gold insert; 3 -capacitive storage; 4 -igniting electrode; 5 -dielectric ring; 6 -pulse shaper; 7 -anode; (b) Cathode assembly of a pulsed vacuum-arc plasma source

The monocrystalline silicon substrate was degreased and placed in a vacuum chamber, which was pumped to a pressure of $1 \cdot 10^{-3} \mathrm{~Pa}$. Before the deposition process the substrate was treated with argon ions using an ion source with a closed electron drift at a discharge voltage of $2.0 \mathrm{kV}$ and a discharge current of $80 \mathrm{~mA}$ for $3 \mathrm{~min}$. The coating thickness was set by the number of discharge pulses and was determined previously on transverse chips using a QUANTA 600 FEG scanning electron microscope.

Four types of coatings were investigated: a carbon coating containing $1 \%$ gold $(\mathrm{C}: 1 \mathrm{Au}), 5 \%$ gold $(\mathrm{C}: 5 \mathrm{Au})$, $25 \%$ gold $(\mathrm{C}: 25 \mathrm{Au})$ with a thickness of $200 \mathrm{~nm}$ and coating based on layers (C-C:25Au-C) with a total thickness of 250-300 nm, C:25Au layer thickness was $200 \mathrm{~nm}$.

To investigate the features of the carbon coatings electronic structure, the size and morphology of gold particles in these coatings, modern analytical methods of high-resolution transmission electron microscopy (HRTEM) were used, including electron energy loss spectroscopy (EELS). Electron energy loss spectra were obtained using Tecnai G2 F20 S-TWIN transmission electron microscope equipped with a 860 Gatan Imaging Filter (GIF) 2001. Accelerating voltage in the column of the transmission electron microscope was $200 \mathrm{kV}$. The convergent beam "nanoprobe" mode was used (the diameter of the probe focused on the sample was about $10 \mathrm{~nm}$ ). The obtained spectra were analyzed in the software package Digital Micrograph v.2.0.2 (background subtraction and deconvolution). The samples for investigation were prepared by the standard method. The coatings previously deposited on a monocrystal $\mathrm{NaCl}$ were separated from the substrate in distilled water and placed onto copper grids specially adapted for transmission electron microscopy with a cell size of 150-200 mesh.
Raman spectra were obtained on LabRAM HR Evolution spectrometer (the wavelength of the laser was $514 \mathrm{~nm}$, the power was $50 \mathrm{~mW}$ ). The coating thickness by the transverse fracture method and their elemental composition were determined using a QUANTA 600 FEG scanning electron microscope. The coating hardness was measured by the method of "instrumental indentation" (ISO 14577-1) using a Dynamic Ultra Micro Hardness Tester Shimadzu DUH-211S at 5, 10 and $25 \mathrm{mN}$ indenter loads. Wear resistance testing was carried out on a laboratory stand according to the "disk - flat sample with coating" scheme under dry friction conditions until complete wear of the coating, which corresponded to the sharp drag of the friction coefficient. The counterbody was a disk with a diameter of $10 \mathrm{~mm}$ made of steel $(\mathrm{Fe} \sim 67, \mathrm{Cr}-17$ $19, \mathrm{Ni}-9-11, \mathrm{Cu} \sim 0.3, \mathrm{Mn} \sim 2, \mathrm{C} \sim 0.12$, all in wt. \%). The load on the disk was $50 \mathrm{~g}$. The studies were carried out at a relative slip speed of $0.5 \mathrm{~m} / \mathrm{s}$. To determine the adhesion/cohesive strength, scratch resistance and the coatings destruction mechanism, the REVETEST scratch tester of CSM Instruments was used. The moment of adhesion or cohesive destruction of the coating was recorded visually after testing (using an optical microscope equipped with a digital camera), as well as based on changes in acoustic emission and friction coefficient. The minimum (critical) load $\mathrm{L}_{\mathrm{c}}$, which led to the destruction of the coating, was determined. The value of the internal stress was determined by laser-optical method from the magnitude of the substrate bending, which was described in detail in [10]. The magnitude of the transmittance was determined using a SF-26 spectrometer.

The electrical resistivity of the film was determined in the temperature range from 320 to $10 \mathrm{~K}$ by the Van der Pauw method using a measuring installation based on a Janis CCS-350S helium cryostat using the relationship:

$$
\rho=\frac{\pi d}{2 \ln 2}\left(R_{12,34}+R_{23,41}\right) f\left(R_{12,34} / R_{23,41}\right),
$$

where $d$ is the thickness of the film, $R_{12,34}$ and $R_{23,41}$ are the resistances calculated from the ratios:

$$
R_{12,34}=\frac{U_{34}}{I_{12}} \quad R_{23,41}=\frac{U_{41}}{I_{23}} .
$$

The function $f\left(R_{12,34} / R_{23,41}\right)$ determines the correction for the difference of the sample shape from the square shape [11].

\section{RESULTS AND DISCUSSION}

Fig. 2 shows TEM-images of a carbon coating with a gold content of $1 \%(\mathrm{a}, \mathrm{c})$ and $25 \%(\mathrm{~b}, \mathrm{~d})$. Using HRTEM, it was found that the carbon coating contains nanoscale particles of globular morphology, about $5 \mathrm{~nm}$ in size. The lattice parameters of the particles correspond to the known literary values of those for gold (cubic facecentered lattice, space group $\mathrm{Fm}-3 \mathrm{~m}$, lattice parameter $a=4.0781 \AA$ ) [12]. 


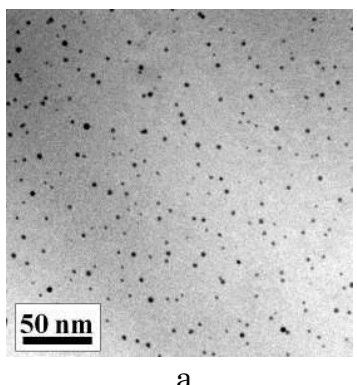

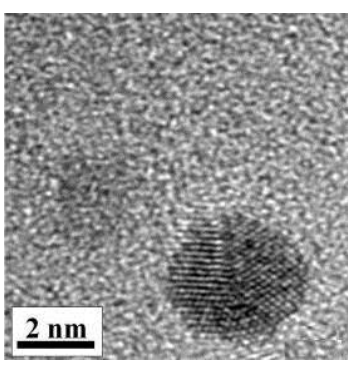

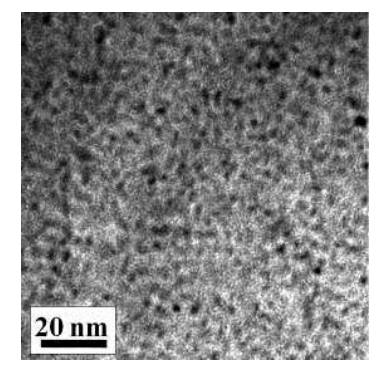

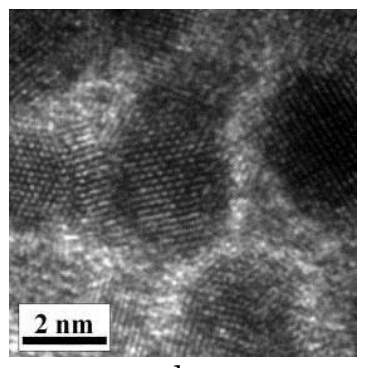

Fig. 2 - TEM-images of the carbon coatings with a gold content of $1 \%(\mathrm{a}, \mathrm{b})$ and $25 \%$ (c, d)

The following regularity in the tested samples was found: an increase in the gold concentration during doping led to an increase in the volume fraction (density) of nanosized gold crystals in an amorphous carbon matrix. The plasmon energy of the carbon matrix for the C:1Au coating obtained using EELS was $30 \mathrm{eV}$. The size of gold nanocrystallites is dependent on the rate at which the material enters the substrate. At small satiety in the case of magnetron sputtering in the metastable region the nucleus of the new phase is formed by overcoming the nucleation energy barrier. This barrier results from the competition of the energetically favorable process of the nucleus volume formation and the energetically unfavorable process of formation of the interface between the nucleus and its surrounding phase, therefore the size of gold nanoparticles is about $20-50 \mathrm{~nm}$ [7]. As supersaturation increases, in the case of pulsed vacuumarc sputtering, the size of the nucleation barrier significantly decreases near the spinoidal curve (the boundaries of thermodynamic stability), which leads to a decrease in the size of gold nanoparticles.

Fig. 3 shows the carbon coating $(\mathrm{C})$, carbon coating with gold content of $1 \%(\mathrm{C}: 1 \mathrm{Au})$ and $25 \%(\mathrm{C}: 25 \mathrm{Au})$. The spectra were analyzed by the position of the $\mathrm{D}$ and $\mathrm{G}$ peaks, by the ratio of their intensities $\mathrm{I}(\mathrm{D}) / \mathrm{I}(\mathrm{G})$, and also by the magnitude of the FWHM (G). The following combination was used to describe the $G$ and $D$ peaks: the BreitWigner-Fano (BWF) loop for peak G and Lorentzian for peak $\mathrm{D}$. The results of the analysis are shown in Table 1.

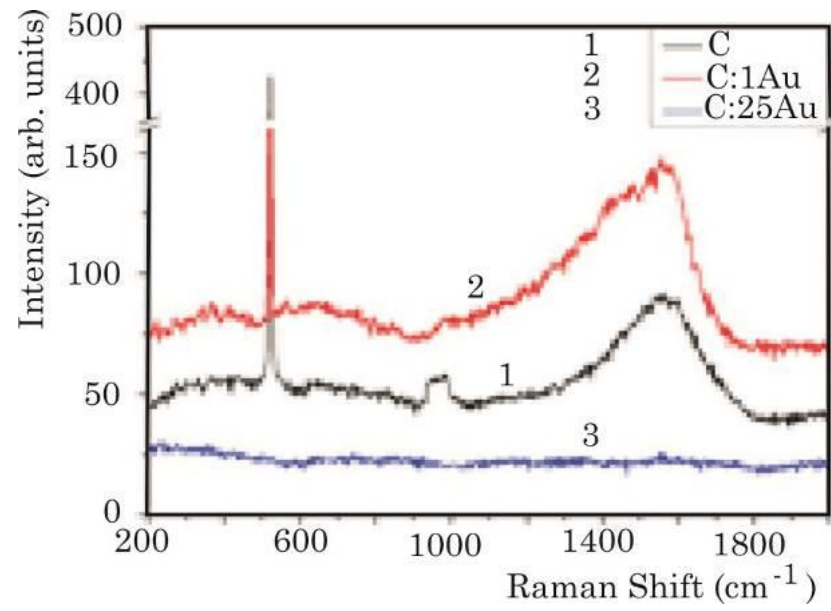

Fig. 3 - Raman spectra of carbon coating (C), carbon coating with gold content of $1 \%(\mathrm{C}: 1 \mathrm{Au})$ and $25 \%(\mathrm{C}: 25 \mathrm{Au})$

Coatings have the same thickness, but different optical transparency, as evidenced by the intensity of silicon lines in the Raman spectra. The presence of $0.6 \%$ gold leads to a decrease in the intensity of the 1st order silicon line (about $520 \mathrm{~cm}^{-1}$ ) by 3 times, and the 2 nd order silicon line (about $960 \mathrm{~cm}^{-1}$ ) becomes barely visible. In the region of $1040-1800 \mathrm{~cm}^{-1}$, the Raman spectrum of a pure carbon coating has one wide asymmetric G-peak, which is described by a single BWF curve. The coating is tetrahedral amorphous carbon (ta-C), the structure of which consists of more than $80 \%$ carbon atoms with $s p^{3}$ hybridization. The content of the $\mathrm{sp}^{3}$-phase was estimated by the position of the $\mathrm{G}$ peak in combination with the condition $I(D) / I(G)=0$ [13]. The $\mathrm{G}$ peak is due to the $s p^{2}$ phase, which is olefin chains embedded in the $s p^{3}$-matrix.

The C:1Au coating is characterized by the appearance of a D-peak in the Raman spectrum, which indicates the clustering of $\mathrm{sp}^{2}$-bonded carbon atoms. The Raman spectrum of carbon coatings correlates with the degree of $s p^{2}$-clustering, and not directly with a fraction of the $s p^{3}$-phase. In this regard, we cannot determine the effect of the gold dopant on the $s p^{3} / s p^{2}$ phase ratio, but we can state that gold leads to the clusterization of $s p^{2}$-bound atoms into ordered hexagonal rings. The Raman spectrum of the C:25Au coating does not contain any characteristic peaks.

Fig. 4 shows the resistivity temperature dependence of the C:25Au coating. Fig. 5 shows the same dependence in Arrhenius coordinates.

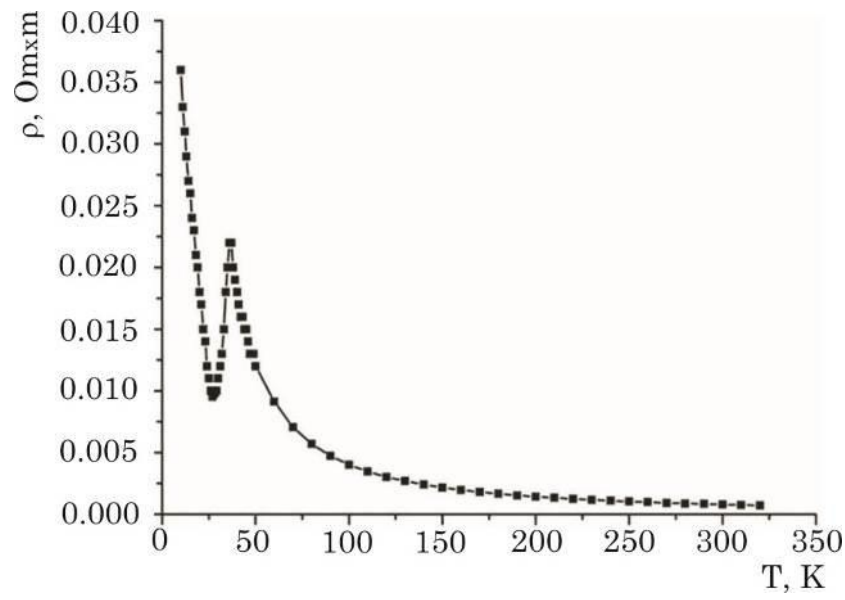

Fig. 4 - Resistivity temperature dependence of C:25Au coating

On the resistivity temperature dependence plotted in the $\ln \rho-1 / T$ coordinates a linear region was not observed (Fig. 5). Therefore, the local activation energy was calculated, and its dependence on temperature is shown in Fig. 6: 


$$
E_{l o c}=k_{B} \frac{d \ln \rho}{d 1 / T} .
$$

Obviously, almost a linear region was observed up to a temperature of $70 \mathrm{~K}$. Its appearance can be explained by the intrinsic conductivity within the framework of the band gap width temperature dependence:

$$
\rho(T)=\rho_{0} \exp \left(\frac{E_{g}}{2 k_{B} T}\right)
$$

For diamond, as well as Si, Ge, 6H-SiC, GaAs, InP and InAs, the temperature dependence of the band gap obeys the Warshny law [14]:

$$
E_{g}(T)=E_{g}(0)-\frac{\alpha T^{2}}{T+\beta},
$$

where $E g(0)$ is the band gap width at $T=0 \mathrm{~K} ; \alpha$ and $\beta$ are constants defined by the material. For diamond, $E g(0)=5.4125 \mathrm{eV}, \alpha=-1.979 \cdot 10^{-4} \mathrm{eV} / \mathrm{K}, \beta=-1437 \mathrm{~K}$. The values obtained in this study for the C:Au film are
$E g(0)=6.96 \cdot 10^{-3} \mathrm{eV}, \quad \alpha=-2.44 \cdot 10^{-4} \mathrm{eV} / \mathrm{K}, \quad \beta=33 \mathrm{~K} . \mathrm{A}$ small value of the band gap is close to graphite, while the sign and magnitude of the constant $\alpha$ are characteristic of diamond.

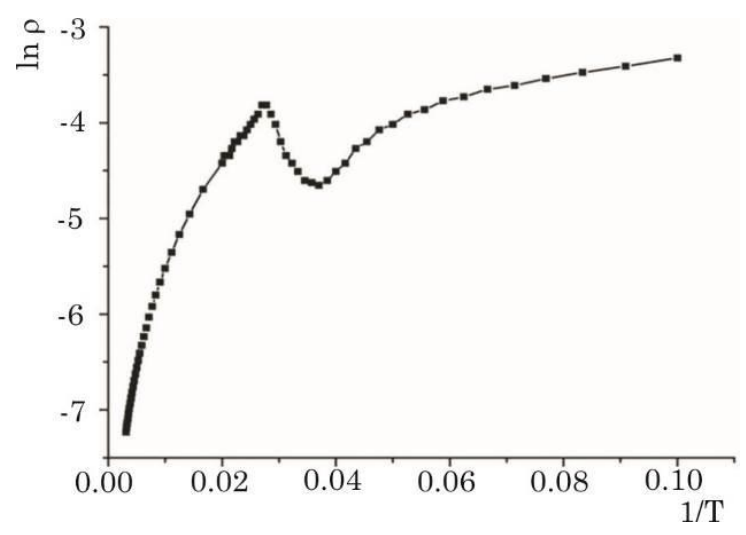

Fig. 5 - Resistivity temperature dependence $\ln \rho-1 / \mathrm{T}$ (Arrhenius coordinates)

Table 1 - The results of the analysis of Raman spectra

\begin{tabular}{|c|c|c|c|c|c|}
\hline Coating & Pos(G), $\mathbf{c m}^{\mathbf{- 1}}$ & FWHM(G), $\mathbf{c m}^{\mathbf{- 1}}$ & Pos(D), $\mathbf{~ c m}^{\mathbf{- 1}}$ & FWHM(D), $\mathbf{c m}^{-\mathbf{1}}$ & I(D)/I(G) \\
\hline C & 1562 & 282 & - & - & 0 \\
\hline $\mathrm{C}: 1 \mathrm{Au}$ & 1572 & 165 & 1416 & 277 & 0.63 \\
\hline
\end{tabular}

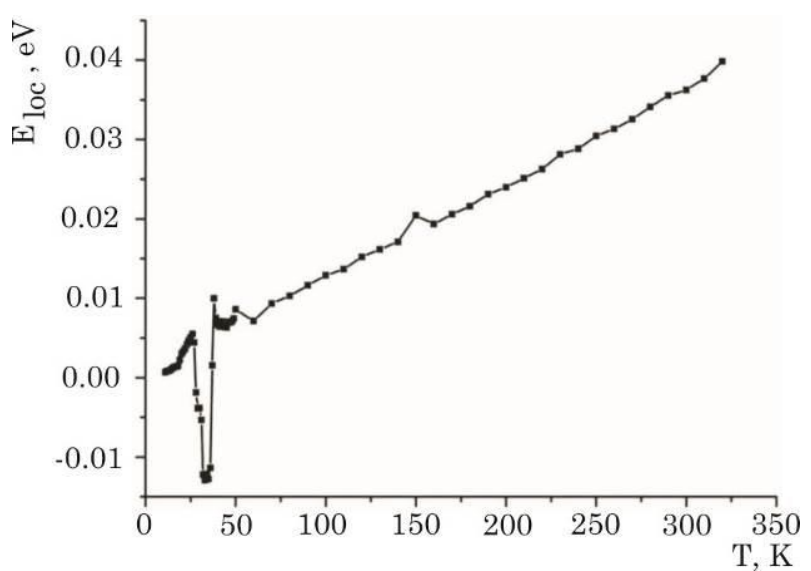

Fig. 6 - Temperature dependence of the local activation energy

In the temperature range from 60 to $37 \mathrm{~K}$, impurity conductivity with the activation energy $E a=7.025 \mathrm{meV}$ is observed, most likely due to the gold impurity. As the temperature further decreases, impurity charge carriers are depleted. Note that all impurities are ionized and, accordingly, the carrier concentration in the zone does not depend on temperature. In this region, the temperature dependence of the resistance is completely determined by the temperature dependence of the mobility, and the decrease in resistance with decreasing temperature is due to the weakening of phonons scattering.

A further decrease in temperature leads to the gradual freezing of impurity charge carriers (i.e., the return of charge carriers to impurity states), which is observed at temperatures from 36 to $19 \mathrm{~K}$. The electrical conductivity temperature dependence here is almost entirely determined by the rapid decrease in the free electron concentration, which leads to an increase in resistance. Below $19 \mathrm{~K}$ the transfer of charge carriers is carried out by the hopping conduction according to the Mott mechanism:

$$
\rho(T)=A T^{m} \exp \left[\left(T_{0} / T\right)^{p}\right]
$$

where $p=1 / 4, m=1 / 4$. The pre-exponential factor $\mathrm{A}$ is equal to $1.607 \cdot 10^{-4} \Omega \cdot \mathrm{m} \cdot \mathrm{K}^{0.25}$, and the characteristic temperature $T_{0} \approx 5552 \mathrm{~K}$. It should be noted that no resistance changes were observed during multiple repetitions of the experiment, which indicates the stability of the coating's electrical properties in the selected temperature range.

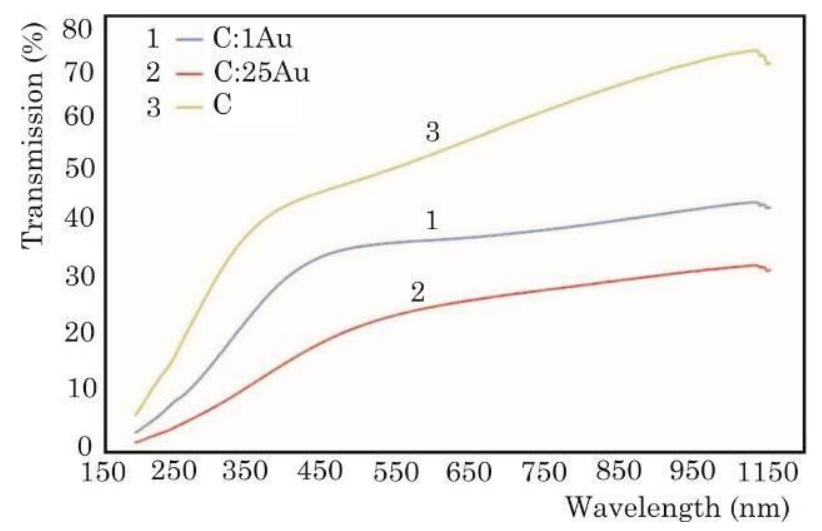

Fig. 7 - The dependence of the transmittance on the wavelength of the carbon coating $(\mathrm{C})$ containing $1 \%$ gold $(\mathrm{C}: 1 \mathrm{Au})$ and $25 \%$ gold (C:25Au)

Fig. 7 shows the dependence of the transmittance on the wavelength for the carbon coating $(\mathrm{C})$, the carbon coating containing $1 \%$ gold $(\mathrm{C}: 1 \mathrm{Au})$ and $25 \%$ gold $(\mathrm{C}: 25 \mathrm{Au})$. An interesting feature of the $\mathrm{C}: 1 \mathrm{Au}$ dependence is almost the same absorption in the range from 450 to $1000 \mathrm{~nm}$, in contrast to the C-coating. For C-coating, a 
monotonous increase in transmittance in this range from 50 to $72 \%$ is observed. For all coatings obtained, almost complete absorption occurs in the ultraviolet region. Thus, C:1Au and C:25Au coatings can be used to protect against radiation in both the $\mathrm{UV}$ and IR ranges. The dependences $\mathrm{C}: 1 \mathrm{Au}$ and $\mathrm{C}: 25 \mathrm{Au}$ differ significantly from the dependences given in [15] by the absence of an increased absorption region in the range of 500-600 $\mathrm{nm}$.

Fig. 8 shows the dependences of the hardness on the maximum indenter load $\left(\mathrm{F}_{\max }\right)$ obtained for the silicon substrate and for the compositions of the silicon substrate with carbon coatings with gold additives. The highest hardness was obtained for the composition of $\mathrm{C}-\mathrm{C}: 25 \mathrm{Au}-\mathrm{C}$, while the hardness increases with decreasing load on the indenter.

Fig. 9 shows the investigation results of the adhesive characteristics of carbon coatings C:25Au (a) and C-C:25Au-C (b). Fig. 10 shows the investigation results of the tribological characteristics of coatings based on carbon and gold. The adhesion characteristics of $\mathrm{C}: 25 \mathrm{Au}$ and C-C:25Au-C coatings have almost the same values; however, the tribological characteristics of $\mathrm{C}$ $\mathrm{C}: 25 \mathrm{Au}-\mathrm{C}$ coating are much higher.

The overall investigation results of all the coatings obtained are summarized in Table 2 . Table 2 shows the obtained values of internal stresses in carbon coatings with different gold content. It can be seen that the value of internal stresses in $\mathrm{C}: 1 \mathrm{Au}$ and $\mathrm{C}: 5 \mathrm{Au}$ coatings is almost the same; a significant decrease in the value of internal stresses is observed only in C:25Au coatings.

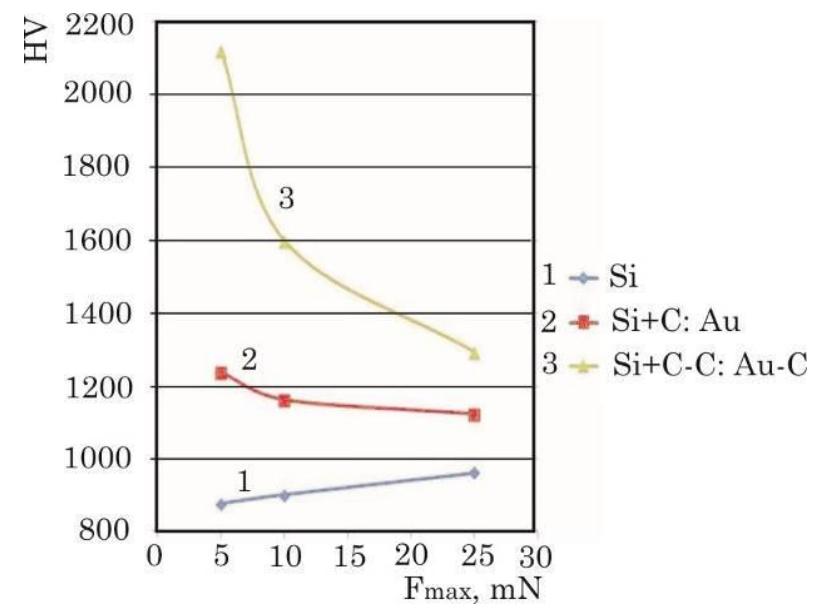

Fig. 8 - Dependence of the hardness on the maximum indenter load $\left(F_{\max }\right)$ of the silicon substrate and the compositions of the silicon substrate with carbon coatings with gold additives

Table 2 - The results of studies of coatings based on carbon and gold

\begin{tabular}{|c|c|c|c|c|c|c|c|}
\hline \multirow{2}{*}{ Coating } & \multirow{2}{*}{$\rho, \mathrm{m} \Omega \cdot \mathrm{m}$} & \multicolumn{2}{|c|}{$\mathrm{K}, \%$} & \multirow{2}{*}{ HV } & \multirow{2}{*}{$S, \mathrm{~m}$} & \multirow{2}{*}{$F, \mathrm{~N}$} & \multirow{2}{*}{ б, $\mathrm{GPa}$} \\
\hline & & $350 \mathrm{~nm}$ & $1000 \mathrm{~nm}$ & & & & \\
\hline $\mathrm{C}: 1 \mathrm{Au}$ & 920 & 25 & 45 & 2000 & 1753.6 & 13 & 11.5 \\
\hline $\mathrm{C}: 5 \mathrm{Au}$ & 0.83 & 18 & 29 & 1800 & 700.0 & 14 & 10.54 \\
\hline $\mathrm{C}: 25 \mathrm{Au}$ & 0.06 & 12 & 33 & 1162 & 350.0 & 37 & 6.3 \\
\hline C-C:25Au-C & 2.4 & 27 & 35 & 1600 & 1224.6 & 30 & 8.0 \\
\hline
\end{tabular}

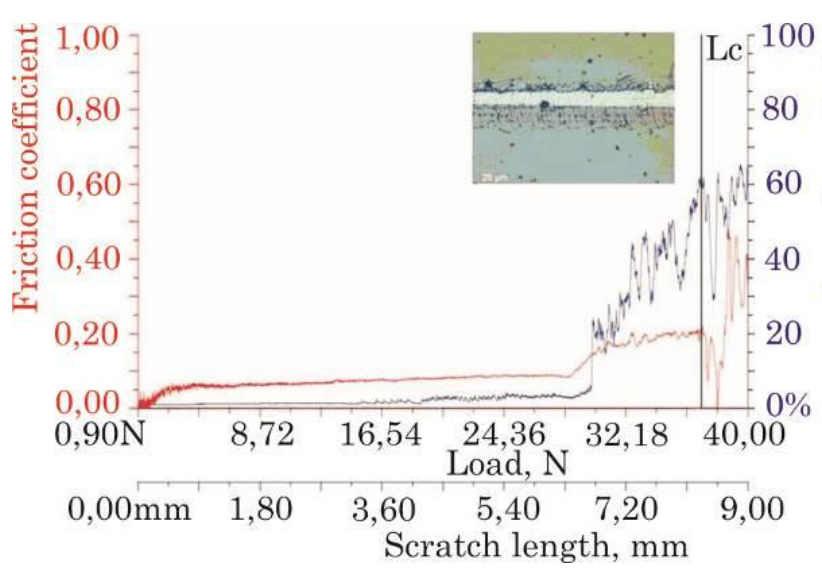

a

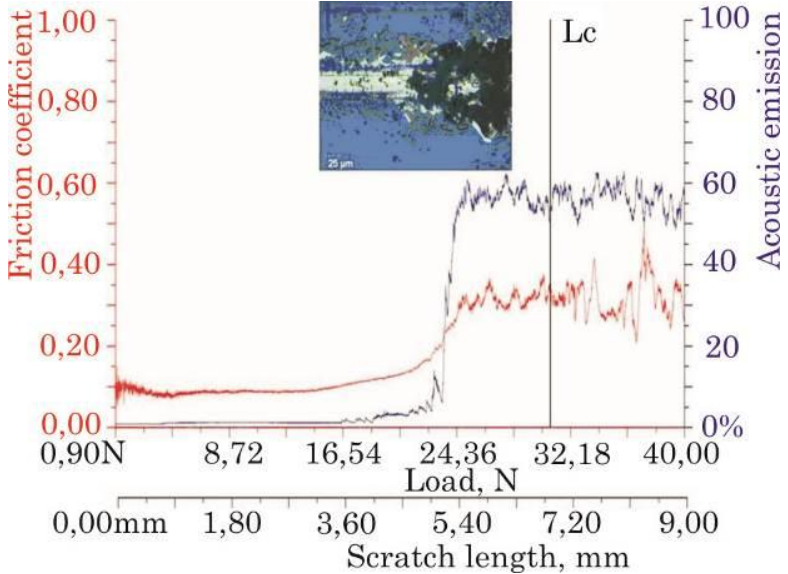

$\mathrm{b}$

Fig. 9 - Scratch test results of carbon coatings: C:25Au (a) and C-C:25Au-C (b)

\section{CONCLUSIONS}

A simple and original method for producing nanostructured coatings based on amorphous carbon and gold nanoparticles using the pulsed vacuum-arc method is proposed. Four types of carbon coatings were investigated: C:1Au, C:5Au, C:25Au and coating based on layers C-C:25Au-C. The carbon coatings contain nanoscale particles of globular morphology, about $5 \mathrm{~nm}$ in size. The lattice parameters of the particles correspond to cubic face-centered lattice. An increase in the gold con- centration led to an increase in the volume fraction of nanosized gold crystals in an amorphous carbon matrix. The electrical properties of the all coatings in the selected temperature range are stability. For all obtained coatings, almost complete absorption occurs in the ultraviolet region. It was found that the most promising composite coating, which has optimal properties (high wear resistance, low friction coefficient, high electrical conductivity and transmittance) is a coating based on layers (C-C: $25 \mathrm{Au}-\mathrm{C}$ ) with a total thickness of 250-300 
nm, C:25Au layer thickness was $200 \mathrm{~nm}$. As a disadvantage, it is necessary to note rather high internal compressive stresses, which can be significantly reduced by annealing in vacuum [16].

\section{AKNOWLEDGEMENTS}

This work was supported by the Russian Foundation for Basic Research and the Belgorod Region Government in the framework of project No.18-42-310001. The studies were carried out on the equipment of the Joint Research Center of Belgorod National Research University «Technology and Materials» and the Centre for High Technologies of Belgorod State Technological University named after V.G. Shoukhov. The authors would like to thank V.S. Vaschcilin (Belgorod State Technological University named after V.G. Shoukhov) for obtaining transmission spectra of coatings.

\section{REFERENCES}

1. M.E. Stewart, C.R. Anderton, L.B. Thompson, J. Maria, S.K. Gray, J.A. Rogers, R.G. Nuzzo, Chem. Rev. 108494 (2008).

2. J.N. Anker, W.P. Hall, O. Lyandres, N.C. Shah, J. Zhao, R.P. Van Duyne, Nat. Mater. 7, 442 (2008).

3. G.V. Naik, V.M. Shalaev, A. Boltasseva, Adv. Mater. 25 No 24, 3264 (2013).

4. O. Kostiučenko, J. Fiutowski, T. Tamulevičius, S. Tamulevičius, D. Silbernagl, H. Sturm, H.-G. Rubahn, Appl. Phys. A 116, 151 (2014).

5. M.R. Hilton, P.D. Fleischauer, Surf. Coat. Technol. 54-55, 435 (1992).

6. S. Miyake, M. Komiya, T. Shindo, Tribol. Lett. 46 No 1, 1 (2012).

7. S. Miyake, T. Shindo, M. Miyake, Tribol. Lett. 61, 6 (2016).

8. A.Ya. Kolpakov, A.I. Poplavsky, S.S. Manokhin, J. NanoElectron. Phys. 8 No 4, 04019 (2016).

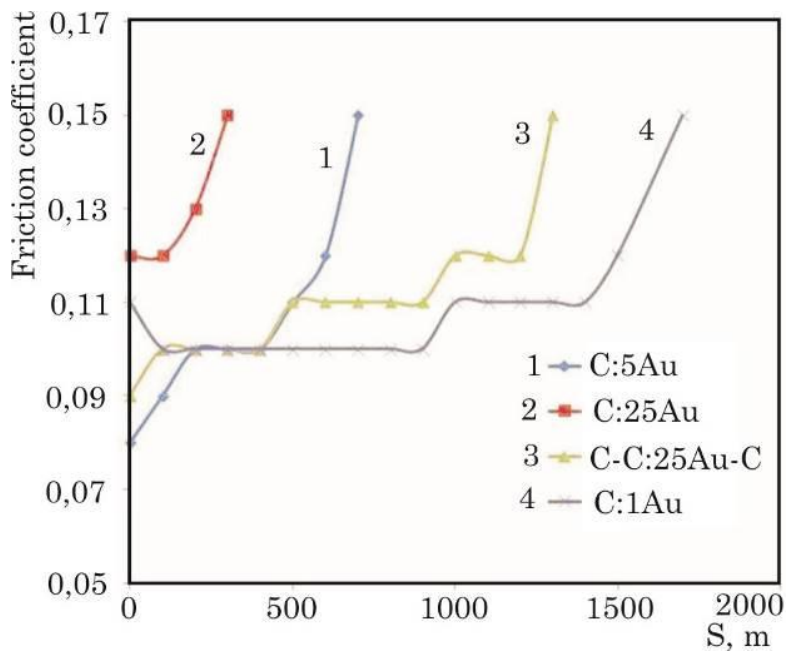

Fig. 10 - Dependence of the friction coefficient on the friction path $(S)$

9. A.I. Poplavsky, A.Ya. Kolpakov, M.E. Galkina, Mater. Today Proc. 5 No 12(3) 25933 (2018).

10. A.Ya. Kolpakov, A.I. Poplavsky, M.E. Galkina, I.V. Sudzhanskaya, O.Yu. Mechansky, Uprochnyayushie Tehnologii i Pokrytiya 4 No 88, 40 (2012).

11. L.J. Van der Pauw, Philips Res. Rep. 13, 1 (1958).

12. M. Ellner, K. Kolatschek, B. Predel, J. Less Common Met. 170 No 1,171 (1991).

13. A.C. Ferrari, J. Robertson, Phys. Rev. B 61 No 20, 14095 (2000).

14. Y.P. Varshni, Physica 34 No 1, 149 (1967).

15. R. Paul, S.R. Bhattacharyya, R. Bhar, A.K. Pal, Appl. Surf. Sci. 257 No 24, 10451 (2011).

16. A.Ya. Kolpakov, A.I. Poplavsky, M.E. Galkina, S.S. Manokhin, J.V. Gerus, Appl. Phys. Lett. 105, 233110 (2014).

\section{Наноструктурні покриття на основі аморфного вуглецю і наночастинок золота, отримані імпульсним вакуумно-дуговим методом}

А.Я. Колпаков ${ }^{1}$, М.Г. Ковальова ${ }^{1}$, В.М. Береснев ${ }^{2}$, С.С. Манохін ${ }^{1,3}$, А.І. Поплавський ${ }^{1,4}$, А.Н. Хмара ${ }^{1}$, М.В. Мішунін ${ }^{1}$, М.Є. Галкіна ${ }^{1}$, Ж.В. Герус ${ }^{1}$, М.Н. Япринцев ${ }^{1}$, В.В. Сирота ${ }^{4}$, О.В.Глухов ${ }^{5}$

${ }^{1}$ Белгородський національний дослідницький університет, вул. Перелоги, 85, 308015 Белгород, Росія ${ }^{2}$ Харківський національний університет іл. В.Н. Каразіна, майдан Свободи, 4, 61022 Харків, Україна ${ }^{3}$ Інститут проблел хімічної фізики РАН, проспект ак. Селенова, 1, 142432 Черноголовка, Росія ${ }^{4}$ Белгородський державний технологічний університет іл. В.Г. Шухова, вул. Костюкова, 46, 308012 Белгород, Росія

${ }_{5}^{5}$ Національний університет радіоелектроніки, бульвар Науки, 14, 61166 Харків, Украӥна

Імпульсним вакуумно-дуговим методом отримані наноструктурні покриття на основі алмазоподібного вуглецю та вуглецю, легованого золотом, товщиною 100-300 нм на підкладках з кремнію. Досліджено структуру методом просвічуючої електронної мікроскопії високої роздільної здатності, елементний склад методом рентгенівського мікроаналізу, визначено твердість, адгезійні та трибологічні характеристики, величину внутрішніх напружень, а також електропровідність і оптичні характеристики. Встановлено, що наночастинки золота у вуглецевій матриці мають кристалічну структуру і розмір близько 5 нм. При змінюванні вмісту золота від 1 до $25 \%$ трибологічні властивості погіршуються, а питомий опір зменшуеться з 920 до 0.06 мОм×х. Запропонована методика легування вуглецевого алмазоподібного покриття золотом дозволяе в широких межах змінювати питомий опір і коефіціент пропускання при збереженні високої зносостійкості і низького коефіцієнту тертя.

Ключові слова: Аморфний вуглець, Наночастинки золота, Імпульсний вакуумно-дуговий метод, Мікроструктура, Електропровідність, Оптичні властивості. 